\title{
Compliance with Statement of Accounting Standard 14 by Listed Oil and Gas Firms in Nigeria
}

\author{
Latifat Muhibudeen $^{1} \&$ Sadiya Abdulrahman ${ }^{1}$ \\ ${ }^{1}$ Department of Accounting, Faculty of Social and Management Sciences, Yusuf Maitama Sule University, Kano - \\ Nigeria \\ Correspondence: Latifat Muhibudeen, Department of Accounting, Faculty of Social and Management Sciences, Yusuf \\ Maitama Sule University, Kano - Nigeria.
}

Received: September 8, 2019

Accepted: November 12, 2019

Available online: November 27, 2019

doi:10.11114/afa.v6i1.4632

URL: https://doi.org/10.11114/afa.v6i1.4632

\begin{abstract}
The study aimed at examining the financial statements of Companies in the Nigerian petroleum industry in other to determine their level of transparency which is a function of their level of compliance with the provisions of Statements of Accounting Standards (SAS) 14 in the upstream sector. Data were collected from annual reports and accounts of the 14 listed oil companies for the period of five years 2013 to 2017. They were analyzed using compliance index, descriptive statistics, correlation and regression. The result reveals that oil and gas companies in Nigeria strongly complied with the requirements of SAS14 with $92.44 \%$. It also shows that the age, size of assets, ROA and Leverage of the companies have insignificantly effect on SAS 14. The study recommends that International Accounting Standard Board, Financial Reporting Council and other relevant regulatory bodies to, as a matter of urgency, commission additional and effective follow up campaigns and supervision aimed at enlightening not only corporate bodies but also individual stakeholders on the benefits derivable from compliance with requirement of SASs.
\end{abstract}

Keywords: compliance, statement of accounting standard, Nigeria petroleum industry, financial statements, disclosure, upstream sector

\section{Introduction}

Financial statement quality is a function of the quality of information provided or disclosed. The disclosure quality can as well be a function of the requirements of accounting standard's provision in the subject matter. According to Ilaboya (2008), accounting standards are rules comprising of best of practices issued from time to time by a duly empowered body. Accounting disclosure is a very paramount factor in financial statement preparation, in any sector. According to Oxford dictionary of accounting (2005), providing or disclosing monetary and non-monetary data, consistently to parties in need of such data as regards the operations of a company. Disclosure requirements are embedded in every accounting standard issued from time to time by the body responsible for standards provision to carter specifically for the uniqueness of the sector in which the standard relates. Disclosure requirements in every standard issued vary from sector to sector depending on the peculiarity of the operations of such sector. For example, the operations in the banking sector differ from those in the manufacturing sector also with the operations of the oil and gas sector. It is also important to acknowledge that some standards exist that cut across board irrespective of the sector in which the organization or company is operating (Endurance, Ebhomenya \& Oselen, 2017).

In U.S, the Financial Accounting Standard Board (FASB) contributes to U.S Generally Accepted Accounting Principles (GAAP) or accounting standards development while in Nigeria, the Nigerian Accounting Standard Board (NASB) now Financial Reporting Council of Nigeria (FRCN) used to contribute immensely to the development of Nigerian GAAP which was the then Statement of Accounting Standard (SAS) before the adoption of the International Accounting Standards (IASs) and International Financial Reporting Standards (IFRSs). It is to be noted that IASs and IFRSs are issued by International Accounting Standard Board (IASB) which was formerly International Accounting Standard Committee (Institute of Chartered Accountants of Nigeria (ICAN, 2014). The accounting standards issued from time to time by this body determine to a large extent what the disclosure quality of the financial statement prepared by organizations adopting these standards will be. Over the years, numerous standards have been issued by IASB, but suffice to say that a few of these standards are actually devoted or assigned to oil and gas companies' usage. Some 
researches on disclosures have centered on the private sector while a little number have centered on the public as well as the quasi sector (non-profit organization) (Oluwagbemiga, 2014). However, little attention has been given to accounting disclosure as it relates to complying with accounting standard in oil and gas sector (Endurance, Ebhomenya \& Oselen 2017).

Financial information is crucial for the economy and the quality of financial statements depends on the accounting standards on which they are based. Financial statement forms the basis on which economic and financial agents, as well as authorities take their decisions. Accounting standards have a direct impact on supervisory work of Department of Petroleum Resources and National Assembly's oversight functions given that petroleum industry operator's account provides detailed overview of the liquidity, profitability and the financial status on the activity of the industry as a whole. Thus, Hope (2003) noted that accounting standards effectively contribute to a further strengthening of financial stability. Izedonmi (2001) on his part opines that the Nigerian Accounting Standards Board (NASB) has improved on its formulation and publication of accounting standards necessary to enhance the safety, soundness and efficiency of book keeping in the petroleum sector.

However, despite the importance and endless benefits that accrue to an economy through application of and compliance with accounting standards, it appears that studies have not been conducted in the area of compliance with the statements of accounting standards i.e. SAS 14 for upstream activities, respectively. There are only few studies on the level of compliance with statement of accounting standards by multinational firms operating in the Nigerian oil and gas sector. Consequently, this study is an attempt to fill this gap. That is to focus on the oil and gas sector and study the level of operators in the upstream sectors of the industry's compliance with statement of accounting standards (SAS).

The main aim of this study is to examine compliance with SAS 14 for listed oil and gas firms. Other specific objective are: to determine the level of compliance of listed oil and gas industry with SAS14; to determine whether compliance with SAS 14 provisions will guarantee disclosure quality; to examine whether compliance with provisions of SAS 14 has an impact on disclosure requirement. Along these angle the following hypotheses guides the study: $\mathbf{H 0}_{1}$ : The level of compliance of listed oil and gas industry with SAS 14 cannot be determined; $\mathbf{H O}_{2}$ : The compliance with SAS 14 provisions would not guarantee disclosure quality; $\mathbf{H 0}_{3}$ : Compliance with provisions of SAS 14 does not an impact on disclosure requirement.

The study attempts to assess compliance with SAS14 of Oil and Gas firms in Nigeria. It is limited to 5years (2013 to 2017). In that regard the paper is organized into five sections; section one covers the introduction, section two reviews the literature, three describes the study methodology, four presents the results and discussed it and five concludes the paper.

\section{Material Studied}

This section reviewed literatures on the concepts, present the review of empirical study and theoretical framework relevant and related to the study.

\subsection{Conceptual Review}

The following concepts were reviewed as it relates to the study.

\subsubsection{The Concept of Financial Statement}

According to Leopold (1989) financial statement as a central feature of financial report are periodic annual reports and accounts as well as other related documents that highlight the financial position of the company and its profitability to assess the financial reporting. The financial position and affairs of the company are the balance sheet; profit and loss account, source and application of fund a few to mention. The company and allied matters Act (CAMA) 1990 required that the financial statement of an organization should include the profit and loss account, the balance sheet, the cash flow statement, the notes to the accounts and some other related books. The report must also comply with the relevant accounting standard board. The Nigerian Accounting Standard Board [NASB] has defined financial reports as being "To provide information about the financial position, performance and financial adaptability of an enterprise that is useful in meeting economic decision".

Financial statement deals with profit and loss account and balance sheet which both reflect depreciation as a major component and a very contentions item. Due to its nature of being a non cash expense so it has a tendency of being tempered with such standards have to be put in place so as to ensure a fair and accurate estimation.

\subsubsection{Concept of Accounting Standard}

Accounting Standard is defined as an information system through which financial and monetized information is generated for economic, social and political decisions (Izedonmi, 2001). Statements of accounting standards are developed to ensure a high degree of standardization, uniformity and comparability in published financial statements. They provide necessary guides on how accounting 
information should be prepared and presented in order to enhance the value of its contents and facilitate thorough understanding. Accounting standards are not only developed to ensure a high degree of standardization and uniformity in the publication of companiese financial statement, they are also useful to all users of accounting information. Multinational oil firms' compliance with accounting standards promotes transparency, comparability, standardization and efficiency in financial reporting.

Accounting standards also have a significant impact on the financial system, in particular their potential influence on the behavior of economic agents. Accounting standards are guidelines which define how companies have to display transactions and events in their financial statements; they are not purely technical rules but the outcome of highly political processes (Fogarty ,Hussein \& Ketz 1994). This means that there are different actors who come to play in influencing accounting standards, examples preparers, managers, accounting firms, auditors, financial analysts, political office holders, legal practitioners and employees. All these actors naturally have divergent views, perception, expectations, options and interests about what an accurate and useful accounting standard is and therefore might have different incentives in the production and diffusion of accounting standards (Giner \& Arce, 2004). Although, academics and practitioners agree on the importance of compliance with the requirements of accounting standards as an essential element of financial reporting, many scholars argue that the extent to which standards are enforced and violations prosecuted are as important as the standards themselves (Sunder 1997). Thus, the quality of financial information is a function of both the quality of accounting standards and the regulatory enforcement or corporate application of the standards (Kothari, 2000). Absence of adequate enforcement, therefore, renders the best accounting standards ineffective and inconsequential. This is because if nobody takes action when rules are breached, the rules remain requirements only on paper. However, in some environments, firms behave towards "mandatory" requirements as if they were voluntary (Giner \& Arce, 2004; Cooper \& Robson, 2005).

The directors and management staff who are entrusted with the running of the affairs of businesses often perceive accounting standards as a set of rules to be circumvented. It is a usual practice to exert financial and moral pressure on the auditors in order to prevent the users of such financial statements from having access to a transparent financial statement.

Accounting standards are applicable to financial statements of a reporting entity that are intended to give a true and fair view of its state of affairs at the balance sheet date and of its profit or loss (or income and expenditure) for the financial period ending on that date. Accounting standards need not to be applied to immaterial items. Accounting standards are not intended to apply to financial statements of overseas entities prepared for local purposes. Where accounting standards prescribe information to be contained in financial statements, such requirements do not override exemptions from disclosure given by law to, and utilized by, certain types of entity. Accounting standards are authoritative statements of how particular types of transaction and other events should be reflected in financial statements and accordingly compliance with accounting standards will normally be necessary for financial statements to give a true and fair view.

In applying accounting standards it is important to be guided by the spirit and reasoning behind them. If in exceptional circumstances compliances with the requirements of an accounting standard is inconsistent with the requirement to give a true and fair view, the requirements of the accounting standard should be departed from to the extent necessary to give a true and fair view.

\subsubsection{Concept of Financial Statement Disclosure}

Disclosure can be defined as a process through which a business enterprise communicates with the external parties. There are three concepts of disclosure generally proposed viz., Adequate, Fair and Full Disclosure. Of these three, the most commonly used is Adequate Disclosure. Fair and full are more positive concepts. Fair disclosure implies an ethical objective of providing equal treatment to all potential financial statement readers. Full disclosure implies the presentation of all relevant information. However, it is contended that there is no difference among these concepts.

Disclosure of information significant to investors and other users should be adequate, fair and full so that it can help them in making economic decisions in the best possible way.

Adequacy of disclosure cannot be tested accurately and precisely since no definite test to measure it exists in financial reporting. But when information is reported outside the business enterprise, adequacy of disclosure can be tested. The basis of the test is the extent to which the items of information are helpful to users in making economic decision. The quantum and quality of information will vary according to the needs of the users.

\subsection{Empirical Review}

In Nigeria and other part of the world, several studies have been carried out on international financial reporting standards, though most of the researchers were geared towards the adoption of IFRS, it is only few that conducted 
on the compliance with IFRSs, depending on the nomenclature used to describe the title of the studies. Studies in Nigeria are very limited when compared with those conducted in other parts of the world, particularly developed economies. Quite a number of studies have been deals with IFRS and other standard, in Nigerian and its environs, this includes:

Okafor and Killian (2011) worked on empirical evidences of Compliance with International Accounting standards, examined the financial statements of 13 listed banks. The findings indicate noncompliance with provisions of national standards that would be useful for inferring group membership despite compliance with other disclosure provisions. This study is not IFRS based.

Onafalujo, Eke and Akinlabi (2011) found that financial measurement model as envisioned by IFRS 4 and 7 are quite relevant to Nigerian financial environment. But there is need to modify to a more restrictive model in the determination of insurance accounting items to enable future compliance to IFRS be efficient. However, the study recommended that from the view of the uniqueness of high volatilities of the Nigerian stock market, low level of actuarial data and experience, and low demand of insurance; the adoption of IFRS for the Nigerian Insurance could be stylized by Nigerian Accounting Standards Board (NASB). Due to the time frame and other prevailing changes this pave way for the study on compliance with IFRS 6 by quoted integrated oil and gas companies in Nigeria.

Oseni (2013) used content analysis method to highlight challenges that are peculiar to Nigeria. Different statutes that are apparently in conflict with the provisions of the standards (IFRS) are to be amended if Nigeria is fully adopting the International Financial Reporting Standards. The study also posits that, terms like balance sheet, value added statements and five- year financial summary recognized by the Companies and Allied Matters Act Cap C20, Laws of the Federation of Nigeria 2004, are to be amended. Significant changes in respect of accounting standards are recommended to be incorporated into the syllabus of tertiary institutions offering accounting courses. Regulatory authorities should step up their supervisory functions on preparers of financial statements to ensure strict adherence to the full provisions of the standards.

Mabruk (2013) assess the adoption and Implication of international Financial Reporting Standards, the study used Major publications and documentary materials emanating from the governments, professional and academic accountants, regulatory accounting bodies and conference proceedings. The study concluded that inadequate preparation and development of Nigerian educational institution by lack of curriculum review and alignment with IFRS and inadequate capacity building by Nigeria auditors and accountant.

Masud (2013) examined the Effect of International Financial Reporting Standards of Financial Reports of Nigerian listed entities, the case of oil and Gas companies. The findings among others revealed that it was only in the Oil and Gas sector heavy investment did not guarantee commensurate returns. The research concluded that a signal global accounting standard has the prospect of improving information quality across the border and will foster border investment. The study recommends further study to use other financial ratio, this might yield different finding.

Sani and Umar (2014) assesses the compliance of IFRS framework at first time adoption by the Quoted Banks in Nigeria using Ex-post factor and survey Research designs. The findings revealed that, Nigerian banks complied with IFRS but some challenges in the sector were lack of indebt knowledge for the preparation of financial statement on IFRS based. This is in line with Yakasai (2014) also assesses the level of compliance with IFRS 7 by listed Banks in Nigeria. A semi structured interview guide was also used to gather data for the study. The overall results show a high degree of compliance with IFRS 7, though not absolute.

Pius, Jane, and Raymond (2014) examined the Impact of the IFRS Adoption on Stock Market Movement in Nigerian Corporate Organization the survey and Ex-post factor Research design was adopted. The Major variables used for this study were earning per Share EPS, leverage size of the company. The major finding of the study is that the share trades in the banks are massive increase from 2011 to 2012 in the banks under study and there is improvement on the shares in Nigerian stock market In recent period.

Muhammad, (2017) assesses compliance with IFRS 4 by listed insurance companies in Nigeria. The study samples 15 insurance companies listed in the Nigeria Stock Exchange (NSE) data were generated from annual reports and accounts of the sampled companies for four years period covering from 2012 to 2015. Descriptive statistics, compliance index, correlation analysis and regression are techniques used to analyzed data. The study shows that listed insurance companies in Nigeria have strongly complied with the requirements of IFRS 4 and there is no variation on compliance.

Muhammad, (2018) assesses compliance with IFRS 6 by quoted integrated oil and gas companies in Nigeria. The study shows that quoted integrated oil and gas companies in Nigeria have strongly complied with the requirements of IFRS 6 with the range of $84 \%$, this is considered to be inadequate, because accounting and reporting standards 
are expected to be complied hundred percent (100\%) a little gap exists between what the companies does and what is required by IFRS 6, this is manifested as a result of challenges faced by Mobil Plc, in 2012-2014, Eterna Plc and Japaul oil and maritime Services Plc in 2012-2013 for inadequacy in their report.

\subsection{Theoretical Framework}

Several theories emerged to explain the conduct of the study on corporate compliance on financial information based on regulatory framework which has been subjected to various influences from enforcement bodies, such theories are heavily dependent on environmental factors which may yield different results and therefore different conclusion were drawn. This is consistent with the position of the American Accounting Associating Committee on Concepts and Standards for External Financial Reports (Al-Shammari, 2005) that financial accounting literature houses numerous theories that presume differences in the user environment and there is no single and universal governing theory of financial reporting and compliance with the specified standard. The choice of a theory depends on the nomenclature and the requirement of the study. These theories could be apply as an essentially to shape the study of this nature.

(a) Signaling theory: The argument of the theory is that companies comply and disclosed information in financial statements to signal superior performance for shareholders, potential investors, corporate and regulatory bodies including other market participants. Barde (2009) and Ben (2013) argued in different dimensions that compliance to International Accounting Standards by profitable companies is one way of signaling their superior performance to the market.

(b) Codification and Regulatory Theory: These theories sometime used interchangeably, the emphasis on this theories are entirely based on compliance with a specific regulations as that of reporting standard the regulatory theory assumed to have the best interest of the society at heart. However, it is very complicated to decide on the right amount of regulation due to the nature of the information and the differences in users' needs (Scott, 2003).

If the afore mentioned theories are examined critically, it can be deduced that the Signaling theory and regulatory theory evidently explain compliance with the specified standard in financial reporting, because the later tries to make emphasis on the assertion that the extent of compliance attract potential investors, stakeholders and on the other hand give confidence to the existing shareholder on the prosperity of the company. While the codification and regulatory theory confirms the authenticity of the activities of standard setters and corporate code that guide the entire issue of compliance with IFRSs. The Codification and signaling theory is adopted to map the credibility of this study by emphasizing on the corporate compliance and link with the maiden objectives of the study.

\section{Methods}

The section explains the methodology of the study which consists of research design, population of the study, sample size and sampling technique. For the purpose of the study expo facto research design was adopted. This selection is because all data proxy for are the variables were extracted from the annual report and audited financial statement of the listed oil and gas companies in the Nigeria. That is Secondary source of data was used

The population of this study comprise of all the 14 oil and gas companies quoted on the floor of the Nigerian Stock Exchange as at July, 2018.

Table 1. Population of the Study

\begin{tabular}{llll}
\hline S/N & Company & Ticker & Year of Listing \\
\hline 1 & 11 Plc & Mobil & 1991 \\
2 & Annino Int. Plc & Anino & 1990 \\
3 & Capital Oil Plc & Capoil Plc & 1990 \\
4 & Conoil Plc & Conoil & 1989 \\
5 & Beco Petroleum Product & Beco & 2009 \\
6 & Eterna Plc & Eterna & 2007 \\
7 & Forte Oil Plc & Forte & 1978 \\
8 & Japaul Oil \& MS Plc & Japaul & 2005 \\
9 & MRS Oil Nig. Plc & MRS & 1978 \\
10 & NavitusEnerge & Navitus & 1993 \\
11 & Oando Plc & Oando & 1992 \\
12 & Rakunity Pet. Plc & Rakunity & 1989 \\
13 & Seplat Pet. Plc & Seplat & 2014 \\
14 & Total Nig Plc & Total & 1979 \\
\hline
\end{tabular}

Source: Nigerian Stock Exchange July, 2018 
Table 2. Describes the Variable of the Study and their Measurements

\begin{tabular}{ll}
\hline Variables & Measurements \\
\hline Compliance index & Measured by the dichotomous of 1 and 0 to obtain Rate of actual score to total score as \\
& used by (Kantudu, 2006), (Barde, 2009), (Ben, 2013), (Yakasai, 2014) and (Muhammad, \\
& 2017 ) \\
& log size, which is the log of total asset as used by (Alsaeed 2005) (Aljifri \& Khasharmeh, \\
& $2006),($ kantudu, 2006), (Barde, 2009), (Ben, 2013) (Sani \& Umar, 2014), (Yakasai, 2014) \\
& and (Muhammad, 2017) \\
& The age of a company was measured from the year listed on the NSE or incorporation as \\
& used in (Al- Shammari 2005), (Kantudu 2006), (Barde 2009), (Ben 2013), (Sani \& Umar \\
Company Age & 2014) and (Muhammad, 2017) \\
& Return on assets (ROA), expressed as profit after tax to total assets ratio, as used in \\
& (Ben, 2013) and (Muhammad, 2017) \\
Profitability (ROA) & This is the total debt to total asset ratio, as used in (Ahmed \& Naser, 1995) and \\
& (Muhammad, 2017) \\
\hline
\end{tabular}

Source: Muhammad (2017)

This study adopts and modified the multiple function of (Pius, Jane \& Raymond, 2014) and Long (2014) as follows.

$$
\mathrm{TCI}=\mathrm{a}_{0}+\mathrm{a}_{1} \mathrm{~S}_{\mathrm{it}}+\mathrm{a}_{2} \mathrm{~A}_{\mathrm{it}}+\mathrm{a}_{3} \mathrm{P}_{\mathrm{it}}+\mathrm{a}_{4} \mathrm{~L}_{\mathrm{it}}+\mathrm{a}_{5} \mathcal{E}_{i t}
$$

Where:TCI $=$ Total compliance index

$\mathrm{S}=$ Size of Asset

$\mathrm{A}=$ Age of the company

$\mathrm{P}=$ Profitability

$\mathrm{L}=$ leverage

$\mathrm{a}_{0}=$ Intercept

$\mathcal{E}=$ an error term assumed to satisfy the standard OLS

$\mathrm{i}=$ entity

$\mathrm{t}=$ time

\section{Results and Discussion}

This section presents the results of the analysis conducted on the data collected from the annual reports and accounts of the sampled oil and gas companies for the period of the study. It presents the descriptive statistics, correlation and regression results of the study.

\subsection{Descriptive Statistics}

The descriptive statistics shows the mean and standard deviation of each independent variable from the mean and standard deviation of the dependent variable.

Table 3. Descriptive Statistics of the Variable

\begin{tabular}{llllll}
\hline Variables & $\mathrm{N}$ & Minimum & Maximum & Mean & Std. Deviation \\
\hline TCI & 70 & 74 & 100 & 98.04 & 5.265 \\
CSIZE & 70 & 5.737 & 9.304 & 7.84666 & .770995 \\
CAGE & 70 & 1.000 & 39.000 & 21.95714 & 11.035431 \\
ROA & 70 & .000 & .807 & .14656 & .207367 \\
LEV & 70 & .046 & 1.737 & .73426 & .367590 \\
Valid N (listwise) & 70 & & & & \\
\hline
\end{tabular}

Source: Computed using SPSS

Table 3 shows the descriptive statistics result of the dependent and independent variables. A total of 70 observations were recorded. The table shows the mean and standard deviation with minimum and maximum range of the dependent and independent variables. On average the total compliance index (TCI) has a mean of 98.04 at a minimum point of 74 and a maximum point of 100 with standard deviation of 5.265representing $5.26 \%$ showing that there is much variation among the TCI of the sampled companies. The company size (CSIZE) has a mean of 7.846at a minimum point of 5.737 and a maximum point of 9.304 with standard deviation of 0.770 representing $77 \%$ showing that there is much variation among the CSIZE of the sampled companies. The company age (CAGE) has a mean of 21.957at a minimum point of 
1.000 and a maximum point of 39.000 with standard deviation of 11.035 representing $11.03 \%$ showing that there is much variation among the CAGE of the sampled companies. The return on assets (ROA) has a mean of 0.146 at a minimum point of 0.000 and a maximum point of 0.807 with standard deviation of 0.207 representing $20.7 \%$ showing that there is no much variation among the ROA of the sampled companies. The company leverage (LEV) has a mean of 0.734 at a minimum point of 0.046 and a maximum point of 1.737 with standard deviation of 0.367 representing $36.76 \%$ showing that there is moderate variation among the LEV of the sampled companies.

\subsection{Correlation Result}

The correlation result shows the relationship between each independent variable and the dependent variable. The values of the correlation coefficient range from -1 to 1 . The sign of the correlation coefficient indicates the direction of the relationship (positive or negative) the absolute value of the correlation coefficient indicates the strength, with larger values indicating stronger relationships and lower values indicating weak relationships. The correlation coefficients on the main diagonal are 1.0, because each variable has a perfect positive linear relationship with itself.

Table 4. Correlation result

\begin{tabular}{|c|c|c|c|c|c|c|}
\hline Variables & & TCI & CSIZE & CAGE & ROA & LEV \\
\hline \multirow[t]{3}{*}{ TCI } & Pearson Correlation & 1 & .124 & .061 & .119 & .004 \\
\hline & Sig. (2-tailed) & & .307 & .614 & .328 & .974 \\
\hline & $\mathrm{N}$ & 70 & 70 & 70 & 70 & 70 \\
\hline \multirow[t]{3}{*}{ CSIZE } & Pearson Correlation & .124 & 1 & $.237^{*}$ & -.136 & $-.307^{* *}$ \\
\hline & Sig. (2-tailed) & .307 & & .049 & .262 & .010 \\
\hline & $\mathrm{N}$ & 70 & 70 & 70 & 70 & 70 \\
\hline \multirow[t]{3}{*}{ CAGE } & Pearson Correlation & .061 & $.237^{*}$ & 1 & -.184 & $.236^{*}$ \\
\hline & Sig. (2-tailed) & .614 & .049 & & .128 & .049 \\
\hline & $\mathrm{N}$ & 70 & 70 & 70 & 70 & 70 \\
\hline \multirow[t]{3}{*}{ ROA } & Pearson Correlation & .119 & -.136 & -.184 & 1 & $.612^{* *}$ \\
\hline & Sig. (2-tailed) & .328 & .262 & .128 & & .000 \\
\hline & $\mathrm{N}$ & 70 & 70 & 70 & 70 & 70 \\
\hline \multirow[t]{3}{*}{ LEV } & Pearson Correlation & .004 & $-.307^{* *}$ & $.236^{*}$ & $.612^{* *}$ & 1 \\
\hline & Sig. (2-tailed) & .974 & .010 & .049 & .000 & \\
\hline & $\mathrm{N}$ & 70 & 70 & 70 & 70 & 70 \\
\hline
\end{tabular}

Source: Computed using SPSS

Table 4 shows the correlation result of the dependent variable TCI and the independent variables CSIZE, CAGE, ROA and LEV. The relationship between TCI and independent variable CSIZE is positive but weak with a coefficient value of 0.124 representing $12.4 \%$, this means that, all things being equal the higher the CSIZE the higher the TCI. The relationship between TCI and independent variable CAGE is positive but weak with a coefficient value of 0.061 representing $6.1 \%$, this means that, all things being equal the higher the CAGE the higher the TCI. The relationship between TCI and independent variable ROA is positive but weak with a coefficient value of 0.0 .119 representing $11.9 \%$, this means that, all things being equal the higher the ROA the higher the TCI. The relationship between TCI and independent variable LEV is positive but weak with a coefficient value of 0.004 representing $0.4 \%$, this means that, all things being equal the higher the LEV the higher the TCI.

\subsection{Regression Result}

The regression result shows the impact of each independent variable to the dependent variable. The regression coefficient values indicate the extent of the impact which range from $0 \%$ to $100 \%$. This section also presents the $\mathrm{F}$ statistics, R2 and adjusted R2 of the model.

Table 5. Regression Results

\begin{tabular}{lllll}
\hline $\begin{array}{l}\text { Dependent Variable: TCI } \\
\text { Variable }\end{array}$ & Coefficient & Std. error & t-statistic & prob.t \\
\hline Constant & 92.993 & 7.750 & 11.999 & .000 \\
CSIZE & .565 & .952 & .593 & .555 \\
CAGE & .058 & .072 & .805 & .424 \\
ROA & 6.160 & 4.443 & 1.387 & .170 \\
LEV & -2.118 & 2.733 & -.775 & .441 \\
R-squared & .214 & & & \\
Adi. R-squared & .046 & & & \\
F-statistic & .781 & & & \\
Prob. (F-statistic) & .542 & & & \\
\hline
\end{tabular}


Source: Computed using SPSS

$$
\begin{gathered}
\mathrm{TCI}_{\mathrm{it}}=\beta_{0}+\beta_{1} \mathrm{CSIZE}_{\mathrm{it}}+\beta_{2} \mathrm{CAGE}_{\mathrm{it}}+\beta_{3} \mathrm{ROA}_{\text {it }} \beta_{4} \mathrm{LEV}_{\text {it }} \mathrm{e} \\
\mathrm{TCI}=92.993+0.565 \mathrm{CSIZE}+0.058 \mathrm{CAGE}+6.160 \mathrm{ROA}-2.118 \mathrm{LEV}
\end{gathered}
$$

Table 5 shows regression results of the model. The model consists of dependent variables TCI and independent variables (CSIZE, CAGE, ROA and LEV). The impact of independent variable CSIZE on dependent variable TCI is positive with coefficient value of 0.565 , meaning that an increase in CSIZE by one unit while other variable remains constant lead to an increase in TCI by $56.6 \%$. The impact of independent variable CAGE on dependent variable TCI is positive with coefficient value of 0.058 , meaning that an increase in CAGE by one unit while other variable remains constant lead to an increase in TCI by $5.8 \%$.

The impact of independent variable ROA on dependent variable TCI is positive with coefficient value of 6.160 , meaning that an increase in ROA by one unit while the t-cal of CAGE is 0.058 which is less than 2.353 therefore; the null hypothesis is accepted which states that compliance with SAS 14 provisions would not guarantee disclosure quality.

With respect to Adj. $\mathrm{R}^{2}$ is 0.046 which is less than 2.353 therefore; the null hypothesis three which states that Compliance with provisions of SAS 14 does not have impact on disclosure requirement.

$$
\begin{gathered}
\mathrm{TCI}_{\mathrm{it}}=\beta_{0}+\beta_{1} \mathrm{CSIZE}_{\mathrm{it}}+\beta_{2} \mathrm{CAGE}_{\mathrm{it}}+\beta_{3} \mathrm{ROA}_{\mathrm{it}}-\beta_{4} \mathrm{LEV}_{\mathrm{it}+\mathrm{e}} \mathrm{e} \\
\mathrm{TCI}=92.993+0.565 \mathrm{CSIZE}+0.058 \mathrm{CAGE}+6.160 \mathrm{ROA}-2.118 \mathrm{LEV}
\end{gathered}
$$

Table 5 shows regression results of the model. The model consists of dependent variables TCI and independent variables (CSIZE, CAGE, ROA and LEV). The impact of independent variable CSIZE on dependent variable TCI is positive

Other variable remains constant lead to an increase in TCI by over $6.16 \%$. The impact of independent variable LEV on dependent variable TCI is negative with coefficient value of -2.11 , meaning that an increase in LEV by one unit while other variable remains constant lead to a decrease in TCI by $2.11 \%$.

The f-statistic from the table is 0.781 which mean that a model with a larger $\mathrm{f}$ statistic indicates that the model account for the variation in the dependent variable and is statistically insignificant with the p-value is 0.542 which is greater than 0.005. In the model the multiple coefficient of determination $\mathrm{R}^{2}$ is 0.046 . This means that $4.6 \%$ of change in TCI was caused by changes in independent variables CSIZE, CAGE, ROA and LEV while the $95.4 \%$ change in TCI was caused by other factors not included in the model.

\subsection{Test of Hypotheses}

In order to decide whether to reject or accept the null hypothesis at 0.05 level of significant, the rejection point is use which states that. (1) If $t_{\text {cal }}>t_{\alpha}$ (where $t_{\text {cal }}$ is the computed t-statistics and $t_{\alpha}$ is the critical value of the distribution table), the null hypotheses is rejected and the alternate hypotheses is accepted; (2) if the $t_{\text {cal }}<t_{\alpha}$ this means that, the null hypotheses is accepted and the alternate hypotheses is rejected. The degree of freedom (df) is $\mathrm{K}-1$ (predictors -1 , which is $4-1=3$ ) at 0.05 level of significance. The $t$-value $\left(\mathrm{t}_{\alpha}\right)$ in this study is 2.353 obtained from the critical values for the $t$ distribution table. Table 4.3 shows the t-statistics and their associate 2-tailed p-values used in testing whether a given coefficient is significantly different from zero.

The $t$-cal of CSIZE is 0.565 which is less than 2.353 therefore; the null hypothesis is accepted which states that level of compliance of listed oil and gas industry with SAS 14 cannot be determined.

The t-cal of CAGE is 0.058 which is less than 2.353 therefore; the null hypothesis is accepted which states that compliance with SAS 14 provisions would not guarantee disclosure quality.

With respect to Adj. $\mathrm{R}^{2}$ is 0.046 which is less than 2.353 therefore; the null hypothesis three which states that Compliance with provisions of SAS 14 does not have impact on disclosure requirement.

\section{Conclusion}

Based on the findings the following conclusions were drawn: The quoted oil and gas companies in Nigeria have strongly complied with the requirements of SAS 14 with the range of $92.44 \%$, this is considered to be adequate, however, accounting and reporting standards are expected to be complied hundred percent (100\%). The result from the analysis shows that, the Age, Size of assets, ROA and Leverage of the companies influenced insignificantly by the compliance with SAS 14 and therefore concludes that these factors affects the compliance with the requirement of SAS14 by revealing positive insignificant correlation coefficient.

The study recommends the following, IASB, financial reporting council and other relevant regulatory bodies, as a matter of urgency, commission additional and effective follow up campaigns and supervision aimed at enlightening not 
only corporate bodies but also individual stakeholders on the benefits derivable from compliance with requirement of SASs and other regulations since the compliance is not $100 \%$ by the oil and gas companies in Nigeria, this will promote and enforce compliance with the international financial reporting standards. The study also recommends that, the oil and gas companies in Nigeria should employ the services of effective and efficient audit firms.

\section{Refrences}

Al-fijir, K., \& Khasharmeh, H. (2006). An Investigation into the Suitability of the International Accounting Standards to the United Arab Emirate Environment. International Business Review, 15(5), 505-526. https://doi.org/10.1016/j.ibusrev.2006.05.009

Al-Saeed, K. (2005). The Association Between Firm Specific Characteristics and Disclosure, The Case of Saudi Saudi Arabia. The Journal of American Academyof Business, 7(1), 310-321.

Al-Shammari, B. A. (2005). Compliance with International Accounting Standards by Listed Companies in the Gulf Co-Operation Council Member States: An Empirical Study. University of Western Australia. (Doctoral dissertation).

Barde, I. M. (2009). An Evaluation of Accounting Information Disclosure in the Nigerian Oil Marketing Industry. Department of Accounting, Bayero University, Kano. (Unpublished Doctoral dissertation).

Ben, K. (2013). Adoption of International Financial Reporting Standard Quality of Financial Statement Disclosures. International Journal of Accounting and Financial Reporting, 3(2). https://doi.org/10.5296/ijafr.v3i2.4489

Companies and Allied Matters Act [CAMA] (1990). Laws of Federal Republic of Nigeria. Retrieved from www.nigeria-law.org

Cooper, D., \& Robson, K. (2005). Accounting, Professions and Regulation: Locating the Sites of Professinalisation. Accounting Organisation and Society, 31(4), 415-444. https://doi.org/10.1016/j.aos.2006.03.003

Endurance, S. A., Ebhomenya, R. E., \& Oselen, O. O. (2017). Accounting Standard and Disclosure Quality in Oil and Gas. International journal of advance Academic.

Fogarty, T. J., Hussein, M. E. A., \& Ketz, J. E. (1994). Political Aspects of Financial Accounting Standard Setting in the USA. Accounting, Auditing and Accountability Journal, 7(4), 24. https://doi.org/10.1108/09513579410069830

Giner, B., \& Arce, M. (2004). Lobbying on Accounting Standards: The Due Process of IFRS 2 on Share-Based Payments. (A Paper Presented at the 3rd International Workshop on Accounting and Regulation, Siena, $30^{\text {th }}$ September -2 nd October).

Glaum, M., \& Street, D. (2003). Compliance with the disclosure requirement of German's new market, IAS Versus. US GAAP. Journal of International Financial Management and Accounting, 14(1), 64-100. https://doi.org/10.1111/1467-646X.00090

Hope, O. K. (2003). Firms' Level of Disclosures and the Relative Roles of Culture and Legal Origin. Joseph L. Rotman School of Management, University of Toronto. (Working Paper). https://doi.org/10.2139/ssrn.380000

Ilaboya, O. J. (2008). Advanced financial accounting. Benin, NG: Mindex publisher.

Institute of Chartered Accountant of Nigeria [ICAN]. (2014). Financial Reporting. Berkshire, UK: Emile Woolf International.

Izedonmi, F. O. I. (2001). An Evaluation of the Level of Banks ${ }^{\text {ee }}$ Compliance with Accounting Standards issued by the Nigerian Accounting Standards Board (NASB). The Nigerian Banker. 12-9. Retrieved from http://www.investorwords.com/1957/financial_statement.html

Kantudu, A. S. (2006). Application of Accounting Standards on Employee Retirement Benefits by Quoted Firms in Nigeria. Department of Accounting, Ahmadu Bello University, Zaria. (Unpublished Doctoral dissertation) 231-241.

Kothari, S. P. (2000). The Role of Financial Reporting in Reducing Financial Risks in the Market. In E.S. Rosengren and J.S. Jordan, (Eds.). Building an Infrastructure for Financial Stability. (Federal Reserve Bank of Boston Conference Series No. 44, June 2000: 89-102. Lagos).

Leopold, A. B., \& John, J. W. (1989). Analysis of Financial Statement (5th ed.). New York: McGraw-Hill.

Mabruk, J. A. (2013). The Effect Of Adopting International Financial Reporting Standards On Quality Of Accounting Reports Of Small And Medium Enterprises In Nairobi Country. Business Administration School Of Business, University Of Nairobi. (Unpublish research Project).

Masud, B. (2013). Effect of IFRS Adoption on the Financial Report of the Nigeria Listed Entities (the case study of 
Oil and Gas Companies). The Macrome Review, a Multidisciplinary Journal of Global Macro Trends, 2(7), 9-26.

Muhammad, U. A. (2017). Assessment of Compliance with IFRS 6 by Quoted Integrated Oil and Gas Companies in Nigeria. Bayero University, Kano-Nigeria. (Unpublished).

Muhammad, U. A. (2017). Assessment of Compliance with International Financial Reporting Standard 4 by Listed Insurance Companies In Nigeria. Bayero University, Kano-Nigeria. (Unpublished Masters Thesis).

Okafor, C., \& Killian, O. O. (2011). Potential Effects of the Adoption and Implementation of International Financial Accounting Standards (IFRS) in Nigeria. Department of Accounting, University of Benin, Benin City, 9(2), Retrieved from: www.ajol.info/journals/jorind345

Oluwagbemiga, E. O. (2014). The use of Voluntary Disclosure in Determined the Quality of Financial Statement: Evidencefrom Nigeria Listed Companies. Serbian Journal of Management.

Onafalujo, A. K., Eke, P. O., \& Akinlabi, B. H. (2011). Impact of International Financial Reporting Standards on Insurance Management in Nigeria. Middle Eastern Finance and Economics. Euro Journals Publishing, Inc. Retrieved from http://www.eurojournals.com/MEFE.htm

Oseni, M. (2013). Application And Challenges of International Financial Reporting Standards In Nigeria. Arabian Journal of Business and Management Review (OMAN), 2(5), 124-127. https://doi.org/10.12816/0002373

Oxford Dictionary of Accounting. (2005). (3rd ed.). Oxford, NY:Oxford University Press.

Pius, V.C., Jane, F. N., \& Raymond A. E. (2014). Impact of the IFRS Adoption on Stock Market Movement in Nigerian Corporate Organization. International Journal of Academic Research in Business and Social, 4(9), 3203-3218. https://doi.org/10.6007/IJARBSS/v4-i9/1150

Sani, S., \& Umar, D. (2014). Assessment of Compliance with IFRS Framework at First-Time Adoption by the Quoted Banks in Nigeria. Journal of Finance and Accounting, 2(3), 73.

Scott, T. W. (2003). Incentives and Disincentives for Financial Disclosure. Voluntary Disclosure of Defined Benefit Pension Plan Information by Canadian firms", Accounting Review, 69(1), 26-43.

Sunder, S. (1997). Theory of Accounting and Control. South- Western College Publication.

Yakasai, H. A. (2014). An Assessment of the Level of Compliance with International Financial Reporting Standar 7 by Listed Banks in Nigeria. Department of Accounting, Bayero University, Kano. (Unpublished Dissertation).

\section{Copyrights}

Copyright for this article is retained by the author(s), with first publication rights granted to the journal.

This is an open-access article distributed under the terms and conditions of the Creative Commons Attribution license which permits unrestricted use, distribution, and reproduction in any medium, provided the original work is properly cited. 